\title{
"Entropy and information in scenario modeling of a firm: new approaches in business economics"
}

\begin{tabular}{|c|c|}
\hline AUTHORS & $\begin{array}{l}\text { Marina G. Lazareva iD https://orcid.org/0000-0002-7573-1268 } \\
\text { R http://www.researcherid.com/rid/O-8852-2017 }\end{array}$ \\
\hline ARTICLE INFO & $\begin{array}{l}\text { Marina G. Lazareva (2019). Entropy and information in scenario modeling of a } \\
\text { firm: new approaches in business economics. Problems and Perspectives in } \\
\text { Management, 17(1), 202-215. doi:10.21511/ppm.17(1).2019.18 }\end{array}$ \\
\hline DOI & http://dx.doi.org/10.21511/ppm.17(1).2019.18 \\
\hline RELEASED ON & Monday, 11 March 2019 \\
\hline RECEIVED ON & Thursday, 06 December 2018 \\
\hline \multirow[t]{2}{*}{ ACCEPTED ON } & Thursday, 21 February 2019 \\
\hline & $(\boldsymbol{c c}) \mathbf{E Y}$ \\
\hline LICENSE & $\begin{array}{l}\text { This work is licensed under a Creative Commons Attribution } 4.0 \text { International } \\
\text { License }\end{array}$ \\
\hline JOURNAL & "Problems and Perspectives in Management" \\
\hline ISSN PRINT & $1727-7051$ \\
\hline ISSN ONLINE & $1810-5467$ \\
\hline PUBLISHER & LLC "Consulting Publishing Company "Business Perspectives" \\
\hline FOUNDER & LLC "Consulting Publishing Company "Business Perspectives" \\
\hline & ニニシ \\
\hline NUMBER OF REFERENCES & NUMBER OF FIGURES \\
\hline 37 & 3 \\
\hline
\end{tabular}

(C) The author(s) 2021. This publication is an open access article. 


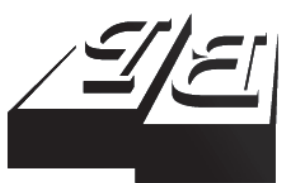

BUSINESS PERSPECTIVES

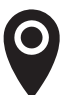

LLC "CPC "Business Perspectives" Hryhorii Skovoroda lane, 10, Sumy, 40022, Ukraine

www.businessperspectives.org

Received on: $6^{\text {th }}$ of December, 2018 Accepted on: $21^{\text {st }}$ of February, 2019

(C) Marina G. Lazareva, 2019

Marina G. Lazareva, D.Sc.

(Economics), Associate Professor, Professor, National University of "Kyiv-Mohyla Academy”, Ukraine.

\section{(c) (i)}

This is an Open Access article, distributed under the terms of the Creative Commons Attribution 4.0 International license, which permits unrestricted re-use, distribution, and reproduction in any medium, provided the original work is properly cited.

\section{ENTROPY AND INFORMATION IN SCENARIO MODELING OF A FIRM: NEW APPROACHES IN BUSINESS ECONOMICS}

\begin{abstract}
In the present world featuring rapidly changing conditions of external environment, it is crucial for companies to be adaptive and resistant to any types of fluctuations. When creating scenarios of business portfolio development or medium-/long-term planning of firm activities, it is important to evaluate an efficiency of such scenario implementation. Depending on the degree of openness of the system-firm, one can talk about the different degrees of its adaptability and ability to develop. The degree of freedom of the system is determined by its entropy. The number of degrees of freedom determines the system's ability to develop, evolve (in general).
\end{abstract}

Thus, it is important to investigate the influence the entropy and information to a firm - a system and create some appropriate instruments for estimation scenarios of development.

The author studies the adaptive capabilities of a firm - a system to the external environment conditions and draws a conclusion that a reasonable combination of order and chaos is required for a firm's evolutionary development, or one should search for optimal balance between an entropy, as a degree of uncertainty (chaos), and a system awareness, as an indicator of its arrangement.

The author has proposed an index of strategic adaptability for evaluation of business portfolio development scenarios. The use of system's information and entropy as evaluation criteria's for the feasibility of scenarios is proposed.

The offered approach and instruments for evaluation of the firm's asset portfolio development scenarios do not require complex calculations and are convenient enough to be used by any firm, concerned about its adaptability to the external environment conditions in practice.

\section{Keywords}

system adaptation, entropy, information, development scenarios, business portfolio, index of strategic adaptability

JEL Classification D80, G32, G34

\section{INTRODUCTION}

Virtually revolutionary contributions of the recent years in physics, chemistry, biology, and mathematics have broken fundamentally the stereotypes related to the environment at micro- and macrolevels. Moreover, they have not ignored the economic sciences, where the terminological and conceptual categories, originated from multidisciplinary approach, are actively used within investigations. It is referred to such fundamental concepts as dynamic conservative and dissipative processes (systems), chaos, synergetics, fractals, channels, jokers. Actually, "today's science, in general, becomes much more narrative. Formerly, there was an explicit dichotomy: social, mainly narrative sciences on one side, and the science itself, focused on searching for the laws of nature, on the other side. Today, there is no such dichotomy" (Nicolis \& Prigozhin, 2003, p. 47). 
For a long period, the academic economists have been applying a system approach. It was widely used in their considerations on performance of social and economic systems of different types. When referring to application of a system approach to economic phenomena analysis, a system is considered as a unity of goals, resources and structure (as a general matter).

When planning the firm activities for medium- and long-term period, an issue of the efficiency level of instruments of development scenarios under conditions of turbulent environment and rapid changes in the external environment is growing more urgent. To understand this fact, there is a good reason to refer to the approaches of system theory: how a firm interacts with environment, how to define a degree of mutual influence, etc.

From the point of view of GTS, entropy serves as the evaluation criterion for chaos; information is the measure of the orderliness of the system. In scenario modeling of the development of events, these evaluation criteria should be taken into account. How do these indicators affect the system-firm? How to apply them in practice? - the author of the article poses the questions.

Modern scenario planning is based on a fairly complex mathematical apparatus. It is applied expensive software products and high-end expensive analytics. Therefore, such methods are widely used in forecasting the development of regions, industries, even states. For a business, such a tool is rather complicated and expensive. Modern business needs a simple, clear and effective toolkit, which gives a clear idea of the effectiveness of development scenarios.

Thus, the article sets the task of studying the influence of entropy and information on the company-system and searching the tools to assess the effectiveness of the company's development scenarios, allowing finding a balance between development (entropy) and equilibrium (information).

\section{LITERATURE REVIEW}

Scenario analysis is a method of prediction of future indicators based on definite potential events. The experts use scenario analysis to predict potential events for investment portfolio, for example, whether the specific events occur or do not occur. Economists and statisticians use scenario analysis to analyze and predict potential future events, considering alternative worlds - the alternative possible results.

Analysts, economists, managers and directors of the companies, as well as statisticians and other specialists, use scenario analysis to check their plans according to the range of possible scenarios to see what will happen if something goes wrong with a plan. These questions were investigated by Neudachin (2011), Blangard and Vaghorn (1988), Robert (2006), Sutherland and Canwell (2005), Omarov (2011), Yaldin (2011), Wind and Mahajan (1981) (1981), Khromov-Borisov (2013), Pardee
(1996), Axson (2010), Roxburgh (2009), Wilkinson and Kupers (2013), and others.

This is an important method used by the risk management specialists to help companies to ascertain that they do not bear too high risk.

The method of scenario modeling occurred in practical activities and then was being developed in theory. One of the first companies that applied scenario analysis practically was "Shell". For more than 40 years, the company has been using this approach to its activity and places regularly the scenarios at its web-site ${ }^{1}$.

The method is used in the following areas: army, crisis management, investment (for example, refer to Volovikov \& Rebrova, 2013), strategic management, and sociology of management (for example, refer to Feofanov, 2008). AICPA and CIMA, two international accounting associations, that are the most popular worldwide, recommend using the

1 Shell scenarios, modeling and decision making (2017). Retrieved from https://go.shell.com/2F5Yk5Y 
scenario analysis in practice, and have worked out the recommended practices for scenario development $^{2}$. According to these practices, scenario development includes six stages: 1) determination of implementation areas (goals), planning timeframe; 2) description of key drivers to build scenarios around them; 3) data collection and processing; 4) scenario development; 5) analysis of scenario applicability; 6) maintenance and support. Then, it is recommended to evaluate the risks and options for their mitigation when implementing the scenarios.

Therefore, scenario planning, as a manager tool for future visualization and evaluation of company response in various situations, becomes an integral part of the overall process of planning and management for most organizations.

In contrast to a forecast, scenario analysis has nothing to do with extrapolation of the past events or their continuation. Several variants of future developments are worked out depending on probability of each scenario implementation. For example, there can be optimistic, realistic and pessimistic scenarios or stagnation scenario, basic scenario or scenario of technical development. Each scenario is formed accordingly depending on risk degree when implementing the variants of events. A firm chooses the factors that are important for it, and then simulates the scenarios and draws up the plans. Typically, the following factors of external environment, which can significantly affect the company's performance indicators, are considered: changes in the exchange rates, price fluctuations for prime cost components (e.g., energy resources), inflation, situation in industry, etc. Analyst makes a forecast and proposes several options for the course of events, as well as prepares the scenarios. This is a part of regular procedures for strategic management. Quality of these forecasts depends on several factors, including the factor of applicability of the complex mathematical tools and specific software programs in the company, specialist qualification, funding of forecast preparation process and those who have time for performance of this work.

Ringland (2008) specified practical cases of scenario approach implementation in his well-known paper. For example, the author, as a member of the work- ing group of Vision 2000 project focused on scenario creation for ICL company (IT area), together with other team members had been performing a scenario modeling for 10 weeks. The working group concluded that a use of axis of customer needs/requests, business needs/requests, macro-environment and the structures of deliveries is an effective enough model of analysis for scenarios involved in the technological areas. A rating of each of these three scenarios was calculated in the context of a rate of changes (very high, high, medium and low). Such approach helped to reveal the considerable differences between scenarios. Each of them obtained its specific figuration, so the single "optimistic/medium/pessimistic" category cannot be applied to them anymore (Ringland, 2008, p. 80).

Lindgren and Bandhold (2009) studied a history of scenario approach, as well as considered the principles of scenario modeling. The authors based their considerations on the theory of complexity, noting that a rate is one of the aspects of adaptability (adaptation), that is often named as the most important condition of success in rapidly changing external environment. The authors developed TAIDA algorithm, being applied for 10 years while performing the hundreds of projects related to scenario planning for public and private companies. "TAIDA stands for:

- supervision - we monitor the changes and signs of threats and potential opportunities;

- analysis - we analyze the consequences and generate scenarios;

- image creation - we identify opportunities and create perspective of desirable course of events;

- decision making - we evaluate information, determine alternatives and strategies;

- action - we set short-term goals, make the moves" (Lindgren \& Bandhold, 2009, p. 12).

In the opinion of Nikiforova (2009), considering an applicability of scenario planning in the industry, "scenario is a document of analytic and de-

2 Scenario planning: Providing insight for impact (2016). Retrieved from https://www.cgma.org/content/dam/cgma/resources/tools/downloadabledocuments/scenario-planning-tool.pdf 
scriptive nature that reflects a logical sequence of the object development on the basis of scientific hypothesis and provisions, based on studying the development trends" (p. 37). For the purpose of our investigation, we accept the following definition for further considerations: scenario is a variant of firm development over the long-term period with set initial parameters and various event outcomes.

Scenario planning is a method of long-term planning. Scenario planning is applied mainly by present-day major corporations, ministries of specific countries and states, as it requires expensive instruments, and the process itself is time-consuming enough. Moreover, it requires high qualification of specialists and long enough period for development, although the specialized software programs for modeling can be used.

Fink and Schlake (2000) consider scenario integration into the processes of competitive intelligence and strategic management. It includes specific methodological approaches to identification of specific scenario consequences, new strategy development and evaluation of available strategic guiding principles and current strategic decisions. Moreover, they demonstrate how to combine scenarios and early warning systems within the framework of strategic prediction. Managerial concept is based on three key principles: operational thinking, open thinking and strategic thinking.

A group of scientists Vilkkumaa, Liesiö, Salo, and LLmola-Sheppard (2018) developed a model of portfolio to support a choice of such strategic actions, in the cases when an information about scenario probabilities can be incomplete and may depend on the selected actions. This is complex enough mathematical model, suggesting a track of each option value for the course of events. It helps to create a reliable (as it works good enough considering all available information about probability) and active strategy (as it can help to control future), as it is demonstrated in scenarios in the line of the desired course of events.

Salo, Keisler, and Morton (2011) developed an approach named "Portfolio Decision Analysis"3
(PDA). PDA is a theory, methods and practices, aimed at helping people who make the decisions to make a choice from a discrete array of alternatives using mathematical modeling. Use of PDA methods to select a project portfolio is based on (i) development of decision making model, considering the general properties of available project offers and decision maker (DM) preferences for risk and several goals, and (ii) dealing with mathematical (integer-valued) task for optimization that helps to determine the most preferable portfolios subject to corresponding restrictions.

Charles Roxburgh (2009), director of McKinsey London office, gives practical recommendations to the top managers of the companies related to practical application of scenario approach.

Scenario modeling techniques are constantly being improved and developed. If you change the angle of view, then you can find aspects that can enrich the existing tools and increase their effectiveness. So, if you approach from the standpoint of the general systems theory in the views of the company, it can be noted that entropy, as a measure of uncertainty and information, as a measure of the orderliness of a system, can help in this matter. Entropy in management theory is a measure of the uncertainty of system's state or behavior under given conditions, and when equilibrium is reached, it must be either positive or equal to zero. "The growing entropy corresponds to the spontaneous evolution of the system. Entropy thus becomes "an indicator of evolution", or, according to Eddington's apt expression, "the arrow of time" (Prigozhin \& Stengers, 2003, p. 112). Entropy is maximal when the distribution of the probabilities of the system' states is uniformed. The more information there is, the closer the connection, the smaller the entropy. Thus, in order for the system (firm) to evolve, it is necessary that the amount of processed information would be greater than entropy.

Entropy and information are currently being disseminated in various areas of knowledge: econometrics (Mazzuchi, Soofi, \& Soyer, 2008), statistics (Ahmad \& Lin, 1976; Mendi, 2015), information

3 Portfolio of investment traded assets. 
theory (Cover \& Thomas, 2006; Kleeman, 2002; Ju, Zhang, Liu, Pan, Zheng, \& Xu, 2019), forecasting (Sbardella, Pugliese, Zaccaria, \& Scaramozzino, 2018; Guan, Dai, Guan, \& Zhao, 2018; Amigo, Hirata, \& Aihara, 2017; Cuartas \& LopezMenendez, 2013).

Proponents and followers of scenario modeling do not yet apply in their assessments these criteria of development and stability, adopted in the general systems theory. It is interesting for us to investigate the question of the applicability of these criteria for evaluating the development scenarios of a company, so that it is possible to analyze changes in the value of a company depending on the chosen scenario.

Thus, scenarios are applied in various areas of economic activity with more or less success. To support decision making process, the specific and complex enough mathematical tools that simplify a process of scenario modeling are being developed. Unfortunately, scenario analysis application is limited by the large business or massive state institutions due to the expansiveness of the latter. Thus, scenario modeling in its current form does not find its application in the practical activities of companies of medium and even large size. A simpler approach with understandable and inexpensive tools is required.

\section{OBJECTIVE}

The objective of research is as follows: to investigate the effect of entropy and information on the system-firm in scenario modeling and the search for new tools to evaluate the development scenarios of the company. The objectives of the study are creating: a working algorithm for evaluating the development scenarios of a medium-sized/largesized company, special tools for analyzing changes in the value of a company depending on its development options.

\section{THEORETICAL FRAMEWORK OF THE STUDY}

An approach suggesting a combination of scenario modeling methods when generating the strategic alternatives for a firm development and the provisions of the general system theory with regard to application of "information" and "entropy" concepts, describing behavior of a firm - a system when interacting with external and internal environments is applied in this research. For the development of special tools for assessing the development scenarios of the company, the profitability index (investment management) is used (Figure 1).

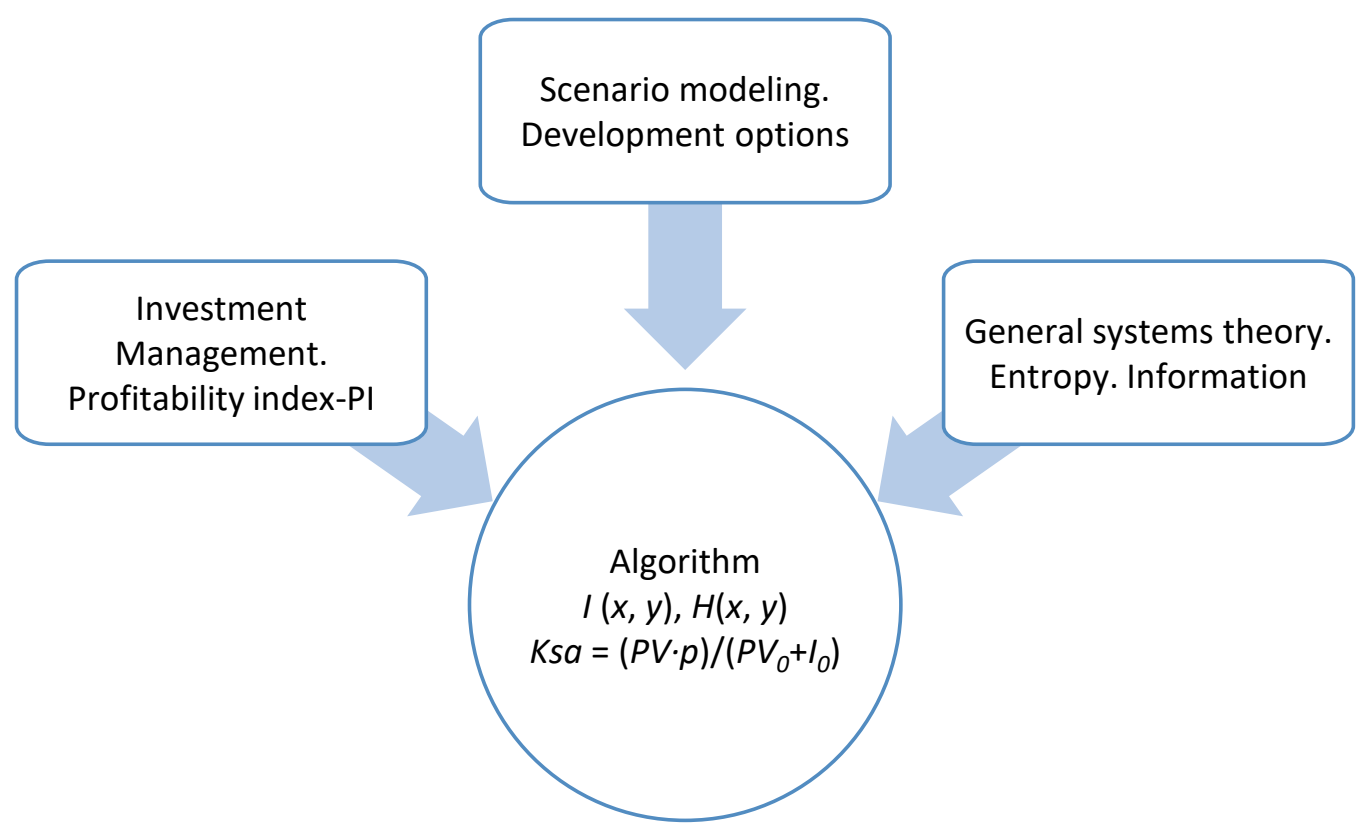

Figure 1. Visual representation of the methodological basis of the study 


\section{RESULTS}

\subsection{Information and entropy}

Practically, a firm - a system determines independently a degree of its publicity (privacy). A level of adaptability and capacity to development depends on a degree of system publicity.

As known, a degree of system freedom is defined by its entropy. A number of freedom degrees determines the system's ability to develop and evolve (in general). The entropy level is the highest in case of even distribution of probabilities for the system conditions and equals to (Ventcel', 1999, p. 473):

$$
H_{\max }(X)=\log _{2} n \text {. }
$$

Entropy peak is a conventional enough value, as any system has the restrictions preventing an unlimited increase of entropy. There is fairly a large number of such restrictions, but, typically, the restrictions to resources are considered for economic systems $-U_{x i}$ (Gagin, 2001, p. 26):

$$
U(x)=\sum_{i} p\left(x_{i}\right) \cdot U\left(x_{i}\right) \leq \text { const } .
$$

This value determines a degree of system privacy, as it limits an entropy increase within a system. Economic system is developed due to its continuous exchange with informational environment, i.e. information resists to entropy increase. At that, information should be entered and processed by a system within the shortest possible time, and in case of the lowest level of disturbances, be presented in the best possible form for perception. According to the formula proposed by Claude Shannon (Ventcel', 1999, p. 254): information contained in the $y$ event (object, state) about the $\mathrm{x}$ event (object, state) can be presented as follows:

$$
I(x, y)=\log _{2} \frac{p\left(\frac{x}{y}\right)}{p(x)},
$$

where $p(x)$ - probability of $x$ event before occurrence of $y$ event (unconditional probability), $p(x / y)$ - probability of $x$ event assuming $y$ event occurrence (conditional probability), $x$ and $y$ events stand for motivation and response, input and output, values of two different variables, peculiar for system condition.

A degree of interconnection between complex open systems in economic system is still an object under study and has not been determined yet. However, some assumptions with a defined level of tolerance that enable to base our further considerations can be determined in a specific way:

1) if a firm - a system (including its separate elements-firms, being its part) is a direct participant of the events, it can influence on them (e.g., events in the market). We mark these events as managed;

2) if a firm - a system is not a participant of the events, but one way or another it uses the results of activity of such events (occurring, for example, in the market) in its activities, we consider that it can not influence on the events in this market. We will mark these events as unmanaged.

In relation to these events, we shall be guided by the following rule: if an event is applicable to the managed category, we act as follows: take steps to change things. If an event is related to unmanaged, we can manage our response to these events. Response management is applicable to a zone of influence of the firm response mechanisms.

Operating principle of feedback mechanism is more evident for managed events than for unmanaged if an observer is in the holding company. But if we imaginatively transfer the observer to the zone of actions for these events (for example, to financial markets), this step enables us to see the feedback action mechanisms, although the observer has already no direct influence on the event. When transferring the observer to the other markets, we can analyze the events considering the feedback actions. Understanding of the operating principle of this mechanism enables not only to analyze the situations, take the corresponding decisions, but also to predict future events most likely than the most of market players.

When responding to internal disturbances within a firm, it is appropriate mostly to refer to the managed events. Moreover, the managing system 
creates these events to develop itself or to be in the state of dynamic stability.

There are three variants of the course of events when a system responds to the disturbing influences: system adapts to new conditions, does not adapt to them or is in the idle state. The latter case can also be considered as a system adaptation variant and can be named "wait-and-see attitude". We can draw an analogy with technical analysis and specify this behavior as "sideways trend". The analysts of stock market consider this position to be uninteresting for conducting operations and prefer not to handle transactions at this time. As to adaptation of a holding company - a system, this behavior is inappropriate, as an acceptance of "wait-and-see attitude" in some cases is the best possible decision.

In general, system adaptation to the new conditions means that a firm - a system accepts them, i.e. a correction of system internal state without substantial reconfiguration takes place. If a system requires such significant efforts for reconfiguration, it is an evidence of the fact that the system has not adapted to the changes and requires a set of measures to provide a new state of dynamic stability. In this case, stability is an indicator of system adaptability.

If we imagine the entropy of some $x-H(x)$ variable system and the entropy of $y$ variable of the same - $H(y)$ system in the form of cycles, we'll see a regularity: the higher entropy is, the higher an area of the circles is. If a correlation ratio between these variables equals 0 (there are no relations between variables), the circles do not intersect. Then, the complete entropy equals to a sum of entropies of these variables (sum of circle areas). If a correlation ratio is greater than 0 (relation is available), the circles will intersect and there will be mutual information $I(x, y)$, being a measure for this intersection. In this case, it is obvious that entropy of two variables is decreased by a value of information, "known" for both variables (Gagin, 2001, p. 31):

$$
H(x, y)=H(x)+H(y)-I(x, y) .
$$

The greater mutual information is, the closer relation and the less $H(x, y)$ entropy are. In order to evolve a system, a scope of processed information has to be larger than entropy. "Dynamics of information processing has to suppress system's entropy environmental conditions" (Gagin, 2001, p. 35). Information is discrete, i.e. is not submitted continuously. At the points of information entry, in case of different degrees of response by the event participants, there may be both points of minimum and maximum. It appears that a principle of maximum information shall be in force.

We can make a conclusion that maximum information will be received by a system that is able to adapt timely to the changes of external environment, keeping internal stability, or by a system that properly and timely responses to the changes due to advanced enhancement and changes of internal state.

Similarly to entropy, maximum information also cannot be achieved in the real world, as it is also limited by the same factors (for example, by resources).

There is a good reason to create the bases of patterns of external environment and firm responses to the various disturbances, raising system dynamic stability, as a collected information in a firm - a system increases its power-to-weight ratio (system energy source or its internal energy increases according to the principle of system power-to-weight ratio: "the higher entropy is, the less energy within a system for operations, actions, and transformations is. But information serves to deal with an entropy. Its growth decreases entropy and increases system power-to-weight ratio" (Gagin, 2001, p. 38). Useful own information, as well as information about environment (thesaurus), that determines system ability to manage, shall be permanently updated for a firm - a system evolving.

Therefore, in order to adapt a firm - a system in the best possible way to the disturbances of internal and external nature, being evolved at the same time, it is necessary to find a balance between an entropy, as a degree of uncertainty (chaos), and a system awareness, as an indicator of its arrangement. A system shall be located within the limits of certain evolutionary passage. 
We consider two completely opposite cases demonstrating this fact. The first case. A system:

1) does not cope with entropy growth;

2) has many degrees of freedom;

3) has minimal restrictions to resources;

4) is not able to process a lot of information (low coefficient of efficiency of information processing).

In this case, we observe explicitly low level of adaptation: system cannot adapt to the environment and perishes. The second case:

1) system is strictly limited by several parameters;

2) entropy increases too slowly;

3) there is a lack of information.

Here there is an explicitly high degree of adaptability, but there is no development (evolving) at all, as there are no motivations to survive.

It is obvious that these cases demonstrate low system efficiency. Therefore, "restrictions to resources, on the one hand, have to assure system vitality and stability, on the other hand - not to afford an opportunity to adapt perfectly to environmental conditions. A state of challenging and effective search for the way out from the changing situations, an optimally balanced scope of obtained information, its processing and implementation have to be provided" (Gagin, 2001, p. 40).

Therefore, a scope of information, processed and implemented by a system within a specific period of time, shall not be lower than an entropy increased during this period. Otherwise, a system degeneration and degradation commence. A scope of entropy within a system shall not decrease rapidly and be comparable to a scope of processed information. Otherwise, we shall deal with stagnation, that is almost similar to the balance. Both balance of the "order" and "chaos" is inappropriate for evolving process.

As to management of a firm - a company in general, when creating scenarios for business portfolio development, it is necessary to calculate the indicators of entropy and information for each scenario and to select basic scenario for development based on more efficient combinations of these parameters.

Combination of the order and chaos within a firm, arising out of continuous exchange with external environment, allows system evolving pursuant to permanent information update inside a firm. Information required for evolving is received from the external environment and has to be timely accepted and used by a firm. It is referred to information, resulting in qualitative changes inside a system (according to a law of evolution), requiring correction of internal structure of a system. For example, new technologies in the industry or new technologies in the related industries, tendency towards occurrence of new needs of the consumers, new financial instruments, etc. (in other words, innovative events in the environment) appear. A firm shall timely response to such changes or adapt to new environmental conditions. "Statistical systems, responding linearly, are doomed to disappear. Their adaptive abilities are exhausted when struggling with more adaptive competitors. New paradigm interprets the markets, as complex, interactive and adaptive systems. Their complexity offers a range of capabilities and interpretations" (Peters, 2000, p. 63).

Disturbances of internal nature within a firm, as a rule, are induced from inside, as it is more effective for a firm to predict independently the further states of environment and to adapt to future events, but not to follow the environmental changes. It is very inefficient to adhere to strategy of leader following. This strategy is often used in the industries and recommended by manuals or consultants. Such firm positioning exhausts a system and results in new state of transition point (bifurcation), requiring strategy modification. This means that in order to develop a system, a managing system (e.g., management company) initiates various actions related to development, being the disturbing influences. I.e., a management system for adaptive mechanisms provides, virtually, a development management that enables a system to perform it systematically. Systematic nature may mean not only smooth reorganization, but also the violent (revolutionary) system changes. 


\subsection{Instruments for the firm development scenario evaluation}

When creating the strategic plans and/or strategies for a firm development, the variants providing both acquisition of new assets and those without such acquisition are considered. For the purpose of our investigation, we will consider an algorithm of scenario composition after determination of the key branches of activities, familiarization with a set of possible asset acquisition, and setting the limits by a scope of investment resource. We consider an action sequence for scenario modeling using illustrative example 4 .

Let us assume that three variants of the course of events depending on a type of new acquired object are provided according to a company development plan. Consequently, an investment amount for acquisition staggers. For the 1st variant, the required amount of investments is $\$ 100,000$, for the 2nd - $\$ 200,000$, for the $3 \mathrm{rd}-\$ 300,000$.

1. We calculate maximum entropy for three potential states:

$$
H_{\text {max }}=\log _{2} 3=1.58496 \text { bit. }
$$

2. Then we will calculate a cash flow based on reporting on the closing date. This is a reference point for our calculations. Let it be $\$ 324,753.66$.

3. We define a forecast interval -5 years.

4. Make a forecast for the cash flows for selected development scenarios excluding investments. We will obtain one value $-\$ 576,688$.9. This is a discounted cash flow; a discounting rate is $10 \%$.

5. After all, we modify investment profitability index (formula 1) as follows (formula 5 into formula 6):

$$
P I=\frac{\sum_{t}^{n} \frac{C F_{t}}{(1+r)^{t}}}{I_{0}}=\frac{P V}{I},
$$

where $P I$ - investment profitability index, $C F_{t}$ cash flow at the time point $t=P V, n$ - number of forecast years (project life cycle), $I_{0}$ - investment amount within a basic period, $r$ - discounting rate (required rate of return),

$$
K_{s a}=\frac{P V \cdot p}{P V_{0}+I_{0}}
$$

where $K_{s a}$ - index of strategic adaptability, $p-$ probability of achievement of $P V$ discounted cash flow value, $P V_{0}$ - cash flow value according to the recent reporting (reference point for increment of cash flows in future).

This index specifies a number of monetary units (dollars) of net income (cost) provided by each monetary unit (dollar) of put out investments and energies upon reaching the set cost level at the end of forecast period. Interpretation of analysis results using this index is as follows:

1) $K_{s a}<1-$ forecast business value is less than a basic business value, which indicates the availability of inefficient investments in case of set probability of the course of events;

2) $K_{s a}=1-$ forecast business value and basic business value are equal. As a result, the investment effectiveness is neutral (does not increase or decrease a cost) in case of set probability of the course of events and indicates the medium level of business adaptability;

3) $K_{s a}>1$ - forecast business value is greater than a basic business value in case of set probability of the course of events. This demonstrates the efficiency of made investments and, consequently, a high level of business adaptability.

6. According to the worked out development scenarios, we know that the amount of investments is within the range from $\$ 100,000$ to $\$ 500,000$. We calculate the indexes of strategic adaptability for the cases, when the investments are allocated from $\$ 100,000$ in increments of $\$ 100,000$ to $\$ 500,000$, and probability of achievement of cash flow value of

4 This simplified example is taken by author from practical calculations made by author for a real business. All calculations and values are factual, but the company name and acquired objects are not disclosed for ethical reasons. 
$\$ 576,688.9$ from 0.8 to 1 in increments of 0.5 and then enter data into Table 1. I.e., formula (2) includes the changing parameters - investments and probability.

Table 1. Calculation of the index of strategic adaptability for $P V_{0}=\$ 324,753.66$ and $P V=\$ 576,688.9$

\begin{tabular}{c|c|c|c|c:c}
\hline \multirow{2}{*}{$\begin{array}{c}\text { Amount of } \\
\text { investments }\end{array}$} & \multicolumn{4}{|c}{ Probability of value achievement } \\
\cline { 2 - 6 } & $\mathbf{0 . 8}$ & $\mathbf{0 . 8 5}$ & $\mathbf{0 . 9}$ & $\mathbf{0 . 9 5}$ & $\mathbf{1}$ \\
\hline 100,000 & 1.09 & 1.15 & 1.22 & 1.29 & 1.36 \\
\hdashline 200,000 & 0.88 & 0.93 & 0.99 & 1.04 & 1.10 \\
\hdashline 300,000 & 0.74 & 0.78 & 0.83 & 0.88 & 0.92 \\
\hdashline 400,000 & 0.64 & 0.68 & 0.72 & 0.76 & 0.80 \\
\hdashline 500,000 & 0.56 & 0.59 & 0.63 & 0.66 & 0.70 \\
\hline
\end{tabular}

Colored part of table may be used as a baseline for decision making, as it demonstrates a zone of effectiveness (adaptability).

For the 1st variant of the course of events (amount of investments is $\$ 100,000$ ), it is obvious that the index of strategic adaptability is greater than 1 , in case of any probability. This means that the 1st variant can be reasonably accepted as a realistic scenario of development, as it is referred to effective investments, giving increments of cost during the forecast period.

For the 2nd variant, if the investments are $\$ 200,000$, a situation is worse, although the index of strategic adaptability is greater than 1 , as it is greater that 1 in case of probability of achievement of values 0.95 and 1 , that is less achievable variant in real-life conditions.

7. For the 3rd variant (amount of investments is $\$ 300,000$ ), index of adaptability is less than 1 . We specify the business value (discounted cash flow value) to make investment process effective. To achieve that, we calculate the index of strategic adaptability according to a formula (2), but specify cash flow value and probability as the changing parameters. Then we will enter data into the table.
Table 2. Calculation of the index of strategic adaptability for $P V_{0}=\$ 324,753.66$ and $I=\$ 300,000$.

\begin{tabular}{l|c|c|c|c|c}
\hline \multirow{2}{*}{ Business value } & \multicolumn{3}{|c}{ Probability of value achievement } \\
\cline { 2 - 6 } & $\mathbf{0 . 8}$ & $\mathbf{0 . 8 5}$ & $\mathbf{0 . 9}$ & $\mathbf{0 . 9 5}$ & $\mathbf{1}$ \\
\hline $576,688.90$ & 0.74 & 0.78 & 0.83 & 0.88 & 0.92 \\
\hline $626,688.90$ & 0.80 & 0.85 & 0.90 & 0.95 & 1.00 \\
\hline $676,688.90$ & 0.87 & 0.92 & 0.97 & 1.03 & 1.08 \\
\hline $726,688.90$ & 0.93 & 0.99 & 1.05 & 1.11 & 1.16 \\
\hline $776,688.90$ & 0.99 & 1.06 & 1.12 & 1.18 & 1.24 \\
\hline
\end{tabular}

We have obtained the intended range for a cash flow in case of set probabilities. The managers analyzed this scenario once more, tried to find additional reserves and specified that it is unlikely to achieve the business value in amount from $\$ 726,688.9$.

8. Thus, after consideration of different variants of investment, the company obtained three variants for decision making:

1 - amount of investments is $\$ 100,000$. High degree of scenario implementation. Expert evaluation of probability for entropy calculation is 0.7

2 - amount of investments is $\$ 200,000$. Medium degree of scenario implementation -0.2 ;

3 - amount of investments is $\$ 300,000$. Low degree of scenario implementation - 0.1.

Let assume that a system can accept only these three states (practically, a process of state modification is continuous and features phase set of probabilities. For a specific case of calculation of a system freedom degree in case of set three variants of events, such limitation is reasonable).

Table 3. Probability of implementation of the firm portfolio development scenarios

\begin{tabular}{c|c:c:c}
\hline & Optimistic & Realistic & Pessimistic \\
\hline$X_{\mathrm{i}}$ & $X_{1}$ & $X_{2}$ & $X_{3}$ \\
\hline $\mathrm{p}_{\mathrm{i}}$ & 0.2 & 0.7 & 0.1 \\
\hline
\end{tabular}


Then an entropy will be equal to:

$$
\begin{aligned}
& H(x)=-(0.2 \cdot \log 0.2+0.7 \cdot \log 0.7+0.1 \cdot \log 0.1)= \\
& =-(0.2 \cdot(-2.322)+0.7 \cdot(-0,515)+0,1 \cdot(-3.322))= \\
& =-(-0.4644-0.3605-0.3322)=1.1571
\end{aligned}
$$

The obtained result demonstrates that a level of entropy in case of such probability allocation is acceptable for implementation of these scenarios (twice as little as the greatest possible). I.e., a degree of freedom, as well as the risks of a firm - a system increase. If we proceed with modeling of potential development scenarios, we can find the best variant of the course of events for specific conditions.

Having a set of patterns of potential states of environment, it is reasonably to analyze the states of a firm - a system (business portfolio development) taking into account the environmental influence. The simplest way is a correction of probability of specific scenario implementation. We will obtain a new value of entropy and can make the appropriate decisions related to scenario modification or its correction.

\section{DISCUSSION}

The obtained results, considered using illustrative example, give reason to believe that a range of available methods of scenario modeling can be supplemented at the last stage prior to final decision making on selection of firm development variant. The proposed index of strategic adaptability allows not only selecting a correct development scenario, but comparing alternative variants of a firm development. The author's investigations and calculations demonstrate that the proposed approach allows coming to conclusion that the index of adaptability and entropy can be used as the criteria of firm development scenario efficiency. The developed index of firm's strategic adaptability enables to evaluate firm development scenarios taking into account the probabilities of implementation of specific scenario and, therefore, helps to make the decisions when selecting a development option. The proposed approach and instruments may be a rationale supplement for the popular methods of scenario modeling: Monte Carlo method (simulation modeling); method of neural connections, applied in case of non-linear relationships of the forecast values; fuzzy sets, described using the linguistic variables and other methods of mathematic modeling. But the approach proposed by the author can be used independently, as it is easy-to-use: no special mathematical knowledge and plenty of time are required, as well as it visualizes information for decision making related to scenario selection.

\section{CONCLUSION}

The idea is as follows: to demonstrate a complexity of interrelations of a firm - a system and the external and internal environments, as well as to prove a necessity of approach revision to forecast the future states of a firm taking into account an influence of entropy and information, as well as a search for instruments for a firm development scenario assessment.

Study of interrelations between a firm - a system and an environment allow coming to the following conclusions:

- system adapts to new conditions of external environment upon the disturbances on its part when a firm accepts such conditions, i.e. a correction of system's internal state without substantial reconfiguration takes place;

- $\quad$ system does not adapt to the changes (within a considered period of time) and requires a set of measures to provide a new state;

- maximum information will be obtained by a firm - a system capable to adapt to the changes of the external environment; 
- to work out the mechanisms of prompt response to the disturbances of different nature, it is reasonable to create the bases of patterns of external environment and a firm itself;

- in order to increase a level of manageability for a firm - a system, a useful own information, as well as information about environment shall be permanently updated for a firm - a system evolving;

- to adapt a firm - a system in the best possible way to the disturbances of internal and external nature, being evolved at the same time, it is necessary to find a balance between an entropy, as a degree of uncertainty (chaos), and a system awareness, as an indicator of its arrangement. A system shall be located within the limits of certain evolutionary passage;

- when creating scenarios of firm development, it is reasonable to calculate the indexes of entropy and information for each scenario.

The paper includes the illustrative example of a procedure (algorithm) for scenario modeling taking into account the probabilities of development scenario implementation. Investment profitability index is modified by a value of scenario implementation probability, as well as an application of new index for scenario modeling is shown. The variant of entropy application when evaluating the firm development scenarios is demonstrated.

The proposed approach to scenario analysis using the index of strategic adaptability and entropy is convenient for practical implementation due to its simplicity and the obtained result reliability. It may be used not only for selection of the best development scenario, but also for analysis of alternative development variants and implementation of local tasks (e.g., planning, in M\&A deals etc.). Using the index of adaptability, we can determine a critical scope of investments for the set scenario parameters.

The author has developed and applied in practice the coefficient of strategic adaptability in the period 2000-2006 in the process of strategic modeling of development options for the "Ukrpodshipnik" group of companies. The application of this coefficient provides a visual representation for the business owner, which greatly facilitates the decision making process - the choice of the forward way. The experience was useful and interesting, according to the owner of the business and top management of the group of companies. The author studied entropy and information without putting it into practice, since there were too few observations and experiments for such experiments.

Further theoretical studies are needed on the applicability of entropy and information when analyzing a firm's development scenarios. The author considers it appropriate to further observe the behavior of these indicators and their impact on the company in practice.

\section{REFERENCES}

1. Ahmad, I., \& Lin, Pi-Erh. (1976). A nonparametric estimation of the entropy for absolutely continuous distributions (corresp.). Information Theory, IEEE Transactions, 22(3), 372-375. https://doi. org/10.1109/TIT.1976.1055550

2. Amigó, J. M., Hirata, Y., \& Aihara, K. (2017). On the limits of probabilistic forecasting in nonlinear time series analysis II: Differential en- tropy. Chaos, 27. https://doi. $\operatorname{org} / 10.1063 / 1.4986394$

3. Axson, D. A. J. (2010). Best Practices in Planning \& Performance Management (3d ed.). N.Y.: John Wiley \& Sons.

4. Axson, D. A. J. (2010). The Management Mythbuster. N. Y. John Wiley \& Sons.

5. Blangard, K., \& Veghorn, T. (1988). Миссия возможного или как стать компанией мирового класса [Missiya vozmozhnogo ili kak stat kompaniey mirovogo klassa]. Chelyabinsk: Ural LTD.

6. Cover, T. M., Thomas, J. A. (2006). Elements of information theory (2nd ed.). Wiley. Retrieved from https://www.amazon.com/ Elements-Information-TheoryTelecommunications-Processing/ $\mathrm{dp} / 0471241954$ 
7. Cuartas, B. M., \& Lopez-Menendez, A. J. (2013). Combining Economic Forecasts by Using a Maximum Entropy Econometric Approach. Journal of forecasting, 32(2), 124-136. http://dx.doi. org/10.1002/for.1257

8. Feofanov, K. A. (2008). O сценарном подходе к прогнозированию [O scenarnom podhode k prognozirovaniyu]. Sotsiologicheskie issledovaniya. Retrieved from http://naukarus. com/o-stsenarnom-podhode-kprognozirovaniyu

9. Fink, A., \& Schlake, O. (2000). Scenario management - an approach for strategic foresight. Competitive Intelligence Review, 11(1), 37-45. http:// dx.doi.org/10.1002/(SICI)15206386(200031)11:13.3.CO;2-N

10. Gagin, V. (2001). Системный синтез "Лезвие жизни" [Sistemnyy sintez "Lezvie zhizni"]. Odessa. Retrieved from http://314159.ru/ gagin/titul.htm

11. Guan, H., Dai, Z., Guan, S., \& Zhao, A. (2018). A Forecasting Model Based on High-Order Fluctuation Trends and Information Entropy. Entropy, 20(9), 669. https://doi.org/10.3390/e20090669

12. Hromov-Borisov, S. N. (2013). Управление сложностью. Операционная система бизнеса. [Upravlenie slozhnostyu. Operatsionnaya sistema biznesa]. M.: Izdatelskiy dom "Grebennikov". Retrieved from https://kniga.biz. ua/book-upravlenie-slozhnostiuoperatsionnaia-sistema-biznesa-003682.html

13. Ju, B., Zhang, H., Liu, Y., Pan, D., Zheng, P., Xu, L., \& Li, G. (2019). A Method for Detecting Dynamic Mutation of Complex Systems Using Improved Information Entropy. Entropy, 21(2), 115. https:// doi.org/10.3390/e21020115

14. Kleeman, R. (2002). Measuring dynamical prediction utility using relative entropy. American meteorological society, 59, 2057 2072. Retrieved from https://nyuscholars.nyu.edu/en/publications/ measuring-dynamical-predictionutility-using-relative-entropy
15. Lindgren, M., \& Bandhold, H. (2009). Сценарное планирование. Связь между будущим и cmpamezueŭ [Stsenarnoe planirovanie. Svyaz mezhdu budushchim i strategiey]. M.: ZAO “OlimpBiznes". Retrieved from https://www.twirpx.com/ file/721107/

16. Mazzuchi, T., Soofi, E., \& Soyer, R. (2008). Bayes estimate and inference for entropy and information index of fit. Econometric Reviews, 27(4-6), 428-456. https://doi. org/10.1080/07474930801960311

17. Mehdi, S. (2015). Essays on Survey and Model Based Economic Forecasts (Theses and Dissertations. Paper 927).

18. Neudachin, V. V. (2011). Реализаиия стратегии компании. Финансовый анализ и моделирование [Realizatsiya strategii kompanii. Finansovyy analiz i modelirovanie]. M: Izdatelskiy dom "DELO". Retrieved from https://www.livelib. ru/book/1000157382/aboutrealizatsiya-strategii-kompanii-finansovyj-analiz-i-modelirovaniev-v-neudachin

19. Nikiforova, V. A. (2009). Сценарный подход к разработке среднесрочной стратегии развития металлургии Украины [Stsenarnyy podkhod $\mathrm{k}$ razrabotke srednesrochnoy strategii razvitiya metallurgii Ukrainy]. Ekonomika promyshlennosti, 5, 37-43. Retrieved from https://cyberleninka. ru/article/n/stsenarnyy-podhodk-razrabotke-srednesrochnoystrategii-razvitiya-metallurgiiukrainy

20. Nikolis, G., \& Prigozhin, I. (2003). Познание сложного. Введение [Poznanie slozhnogo. Vvedenie]. M.: Editorial. Retrieved from http://spkurdyumov.ru/networks/ poznanie-slozhnogo/

21. Omarov, Sh. A. O. (2011). Особенности использования сценарного подхода при формировании стратегии развития компании [Osobennosti ispolzovaniya stsenarnogo podkhoda pri formirovanii strategii razvitiya kompanii]. Problemy ekonomiki, 4, 139-142.
22. Pardee, W. (1996). To satisfy \& delight your customer: how to manage for customer value. N.Y.: Dorset house.

23. Peters, Е. (2000). Хаос и порядок на рынках капитала. Новый аналитический взгляд на ииклы, иены и изменчивость рынка [Khaos i poryadok na rynkakh kapitala. Novyy analiticheskiy vzglyad na tsikly, tseny i izmenchivost rynka]. M.: Mir.

24. Prigozhin, I., \& Stengers, I. (2001). Порядок из хаоса. Новый диалог человека с природой [Poryadok iz khaosa. Novyy dialog cheloveka s prirodoy] (Izd. 4-e, stereotipnoe). M.: Editorial URSS. Retrieved from http://yanko.lib.ru/books/ betweenall/prigogine-stengers ru.htm

25. Ringland, D. (2008). Сиенарное планирование для разработки бизнес-стратегии [Stsenarnoe planirovanie dlya razrabotki biznes-strategii]. M.: OOO "I.D. Vil'yams". Retrieved from http:// www.management.com.ua/books/ view-books.php?id=533

26. Robert, М. (2006). Новое стратегическое мышление. Просто о сложном [Novoe strategicheskoe myshlenie. Prosto o slozhnom]. M.: Pokolenie. Retrieved from http://www.management.com.ua/books/view-books. php?id=418

27. Roxburgh, C. (2009, November). The Use and Abuse of Scenarios. McKinsey Insights. Retrieved from https://www.mckinsey.com/ business-functions/strategy-andcorporate-finance/our-insights/ the-use-and-abuse-of-scenarios

28. Salo, A., Keisler, J., \& Morton, A. (2011). An invitation to portfolio decision analysis. In A. Salo, J. Keisler \& A. Morton (Eds.), Portfolio decision analysis, 162, 3-27. Retrieved from https://link.springer.com/chapter/10.1007/978-1-4419-9943-6_1

29. Sbardella, A., Pugliese, E., Zaccaria, A., \& Scaramozzino, P. (2018). The Role of Complex Analysis in Modelling Economic Growth. Entropy, 20, 883. http://dx.doi. org/10.3390/e20110883 
30. Schwartz, P. (1996). The art of the Long View: Planning for the Future in an Uncertain World. N.Y.: Doubleday.

31. Sutherland, D., \& Canwell, D. (2005). Стратегический менеджмент. Ключевые понятия [Strategicheskiy menedzhment. Klyuchevye ponyatiya]. Dnepropetrovsk: Balans Biznes Buks. Retrieved from https://www.yakaboo.ua/ key-concepts-in-strategic-management-1040195.html?gclid=EAIaIQ obChMI3qXevOLb4AIVjh0YCh3A aAy7EAYYASABEgLoqPD_BwE

32. Ventcel', E. S. (1999). Теория вероятностей [Teoriya veroyatnostey]. M.: Vysshaya shkola.

33. Vilkkumaa, E., Liesiö, J., Salo, A., \& LLmola-Sheppard, L. (2018). Scenario-based portfolio model for building robust and proactive strategies. European journal of operational research, 266(1), 205220. https://doi.org/10.1016/j. ejor.2017.09.012

34. Volovikov, B. P., \& Rebrova, N. Р. (2013). Формирование портфеля проектов промышленного предприятия на основе сценарного планирования [Formirovanie portfelya proektov promyshlennogo predpriyatiya na osnove stsenarnogo planirovaniya]. Vestnik Omskogo universiteta. Seriya "Ekonomika", 3, 178184. Retrieved from https:// cyberleninka.ru/article/n/ formirovanie-portfelya-proektov-promyshlennogo-predpriyatiya-na-osnove-stsenarnogoplanirovaniya
35. Wilkinson, A., \& Kupers, R. (2013, May). Living in the Futures. Harvard Business Review. Retrieved from https://hbr. org/2013/05/living-in-the-futures

36. Wind, Y. J., \& Mahajan, V. (1981). Designing Product and business portfolios. HBR. Retrieved from https://hbr.org/1981/01/designingproduct-and-business-portfolios

37. Yaldin, I. V. (2011).

Когнитивное моделирование в прогнозировании сценариев стратегии устойчивого развития интегрированной структуры бизнеса [Kognitivnoe modelirovanie $\mathrm{v}$ prognozirovanii stsenariev strategii ustoychivogo razvitiya integrirovannoy struktury biznesa]. Problemy ekonomiki, 4, 142-150. 